\title{
An Empirical, Functional approach to Depth Damages
}

\author{
Will Lehman $^{1, a}$, R. Hasanzadeh Nafari ${ }^{2}$ \\ ${ }^{1}$ USACE, 209 Second St, Davis CA, 95616, USA \\ ${ }^{2}$ CDMPS, Deparment of Infrastructure Engineering, The University of Melbourne, VIC 3010, Australia
}

\begin{abstract}
In order to compute direct damages to structures and contents, the United States Army Corps of Engineers (USACE) has traditionally relied on relationships that define damage for a given depth. These relationships are described using paired data relationships of depth and damage. Generally, the curves utilized are based on an Elicitation of Experts (EoE). This paper will present an alternative methodology which takes empirical data of damage and depth, stratified by building classifications, and use Non Linear Least Squares Estimation to fit a parameterized function to compute depth-damage estimates. The general function will be described, and the parameters will be discussed. Parameters include foundation height, ground elevation, percent damages below ground, number of stories, height of stories, maximum damage as a percent, and the beginning elevation for damage. The advantages of this approach include the ability to utilize empirical data, and the ability to change parameters based on building practices across the world. Additionally, the paper will illustrate a bootstrapping approach to the empirical data to assist in describing confidence limits around the parameterized functional depth damage relationship. A Figure (Figure 1) is provided to illustrate the output of the process.
\end{abstract}

\begin{tabular}{|l|l|l|l|l|}
\hline \multicolumn{2}{l}{ Depth } & \multicolumn{1}{l}{ Min } & \multicolumn{1}{l}{ Maxtlikely } & \\
\hline 0 & 0 & 0 & 0 & \\
\hline 1 & 0.441081701219086 & 1.06991144098956 & 3.28485787157047 & \\
\hline 2 & 0.7923953157079 & 1.74948328888168 & 4.71128595503183 & \\
\hline 3 & 1.11627122852219 & 2.33257459162252 & 5.81778914916027 & \\
\hline 4 & 1.42352388371683 & 2.86069637244502 & 6.75713112040015 & \\
\hline 5 & 1.71897921018952 & 3.35137759838101 & 7.58898426290306 & \\
\hline 6 & 2.00536111585626 & 3.81414770585057 & 8.34412610207431 & \\
\hline 7 & 2.28441132877306 & 4.2549265773285 & 9.04091946579595 & \\
\hline 8 & 2.55733496569439 & 4.67771472144286 & 9.6913711912381 & \\
\hline 9 & 2.82501280869848 & 5.08537811358543 & 10.3038462872384 & \\
\hline 10 & 3.08811512739876 & 5.48006019795166 & 10.8844511295946 & \\
\hline 11 & 3.34716808871028 & 5.86341794946011 & 11.4378061523681 & \\
\hline 12 & 3.60259505238008 & 6.2367663500638 & 11.9675083820058 & \\
\hline 13 & 3.85474356401187 & 6.60117149921443 & 12.4764236964138 & \\
\hline 14 & 4.10390372365668 & 6.95751317096847 & 12.9668797144682 & \\
\hline 15 & 4.35032110708501 & 7.30652831012461 & 13.4407977526155 & \\
\hline 16 & 4.59420611172834 & 7.64884215814264 & 13.899785854799 & \\
\hline 17 & 4.83574087874395 & 7.98499107942044 & 14.3452060807881 & \\
\hline 18 & 5.07508452570244 & 8.31543965838305 & 14.778224262307 & \\
\hline 19 & 5.31237717328385 & 8.64059374323902 & 15.1998475096325 & \\
\hline 20 & 5.54774309284266 & 8.96081055971771 & 15.6109529666112 & \\
\hline 21 & 5.78129320117252 & 9.27640666625291 & 16.0123101890533 & \\
\hline & & & &
\end{tabular}

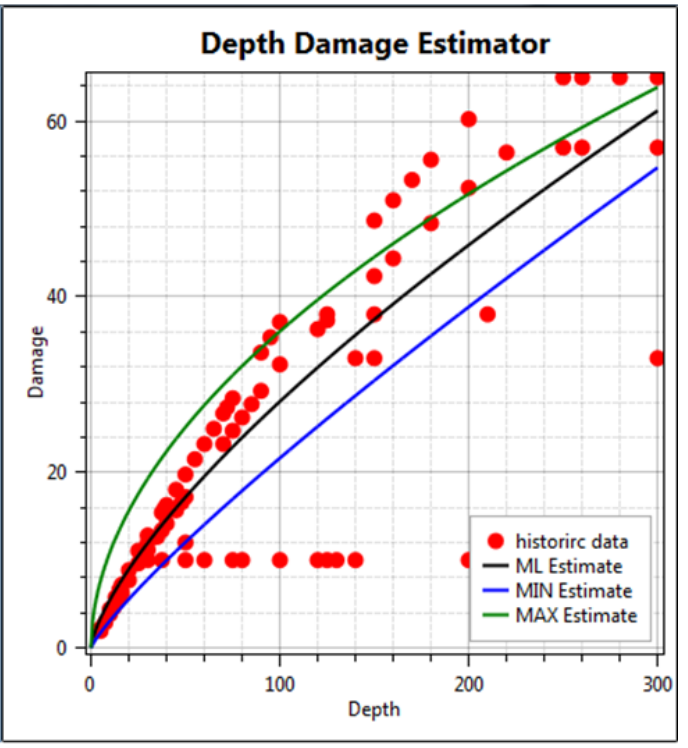

Figure 1

\section{Introduction}

Evaluation of the damages due to flooding are necessary to determine what actions can be taken to reduce the damages of flooding. There are many ways to accomplish the task of determining which projects to implement, but all require some statement of the damages with a project and without a project. The evaluation of the damages from flooding requires some sort of methodology that would account for changes to the nature of the flooding, the things that are exposed to flooding, or the vulnerability of those things that are exposed to flooding.

Generally, the basis of establishing the damages from flooding includes the loss of value of structures due to the flood event. Additionally, there is a strong relationship between deeper depth and greater damage at a structure.

In the field of flood damage assessment, terms such as damage, loss, and impact have various definitions. Broadly, flood damage can be categorized as direct or indirect. In this paper, direct damages are those due to physical contact between the floodwater and the inundated objects, and the indirect damages are based on the effects of direct damage on a wider scale of

\footnotetext{
${ }^{\text {a }}$ Corresponding author : william.p.lehman@usace.army.mill
} 
space and time (Meyer et al., 2013; Molinari et al., 2014a; Thieken et al., 2005).

Both categories may be able to be described as damages that are tangible or intangible (André et al., 2013; Kreibich et al., 2010). Tangible damages refer to damages that are marketable, whereas intangible damages are difficult to express in terms of marketable value. The focus of this study is on direct, tangible damages to buildings due to a short duration of riverine (low-velocity) inundation.

\section{Why flood damage assessment?}

Flood damage assessment is a critical component of flood risk mitigation. To evaluate measures that can be taken to mitigate the damages from flooding, assessment of damages must be conducted. In addition to flood damage assessment, analysis of the measures and their reductions to the without project condition must be conducted. Without clear and reproducible flood damage assessment, analysis is very difficult, and the management of risk is less reliable.

\section{Depth damage relationships}

As stated previously, damages to structures in the floodplain are strongly related to the depths achieved in the structures due to the flooding. There are many other important parameters, but depth describes the majority of the variance of damages when the structures are stratified by construction and use.

Fundamentally, for a given structure, holding all hydraulic constraints (velocity, duration, salinity, and sedimant load) constant, for increasing depths, damages should increase.

For a given construction practice (wood construction, concrete block construction, or steel frame construction), and a given use (residential, or commercial) there could be great variance between the contents of the structures. Additionally, there may be considerable differences in the components of the structure and their elevation relative to the ground. For instance, some two story residential structures may have the laundry room on the first floor, while others may have the laundry room on the second floor. Since the laundry probably would have either gas or high voltage electrical, different components within the structures may get damaged at different depths relative to the first floor or ground level of the structure.

This implies that there is considerable uncertanty in the damage for a give elevation even when use and construction type are held constant.
Structure Depth-Damage

\begin{tabular}{|r|r|r|}
\hline \multicolumn{3}{|c|}{ Table 1 } \\
\hline & One Story, No Basement \\
\hline Depth & Mean of Damage & $\begin{array}{c}\text { Standard Deviation } \\
\text { of Damage }\end{array}$ \\
\hline-2 & $0 \%$ & $0.0 \%$ \\
\hline-1 & $2.5 \%$ & $2.7 \%$ \\
\hline 0 & $13.4 \%$ & $2.0 \%$ \\
\hline 1 & $23.3 \%$ & $1.6 \%$ \\
\hline 2 & $32.1 \%$ & $1.6 \%$ \\
\hline 3 & $40.1 \%$ & $1.8 \%$ \\
\hline 4 & $47.1 \%$ & $1.9 \%$ \\
\hline 5 & $53.2 \%$ & $2.0 \%$ \\
\hline 6 & $58.6 \%$ & $2.1 \%$ \\
\hline 7 & $63.2 \%$ & $2.2 \%$ \\
\hline 8 & $67.2 \%$ & $2.3 \%$ \\
\hline 9 & $70.5 \%$ & $2.4 \%$ \\
\hline 10 & $73.2 \%$ & $2.7 \%$ \\
\hline 11 & $75.4 \%$ & $3.0 \%$ \\
\hline 12 & $77.2 \%$ & $3.3 \%$ \\
\hline 13 & $78.5 \%$ & $3.7 \%$ \\
\hline 14 & $79.5 \%$ & $4.1 \%$ \\
\hline 15 & $80.2 \%$ & $4.5 \%$ \\
\hline 16 & $80.7 \%$ & $4.9 \%$ \\
\hline
\end{tabular}

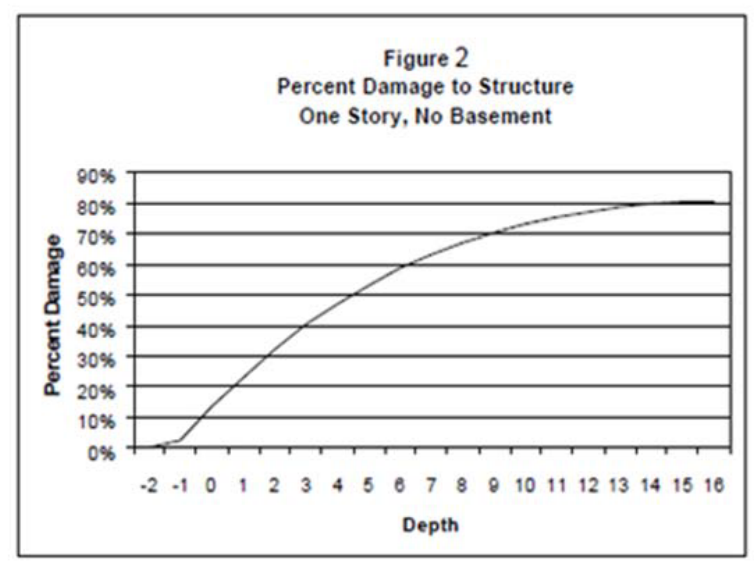

To accomidate that, structures are grouped into like categories, (i.e. Brick houses with 1 story vs Wooden houses with one story, or Metal industrial building vs Masonary Commercial building). Depth damage functions should be described with uncertanty at each depth ordinate, and the curves should be monotonically increasing. Some samples of depth damage relationships would look like this.

These damage functions are for residential structures, and are described in Economic Guidance Memorandum 03-01. These curves are the depth damage relationships USACE personell must use in flood risk mitigation analysis for residential structures. There are no defined commercial or industrial depth damage relationships for USACE. The reason for this paper is to provide a methodology to allow users to create depth damage relationships with uncertainty based on observable parameters, and emprical data.

Since construction practices may vary from region to region, Emperical data and fitting methodologies have been developed to assist in regonalizing the functional relationships. 


\section{Evaluating the maximum damageable value}

A significant parameter in evaluating the damage to a structure from flooding is the overall suceptibility of the structure to flooding. Some structures may have very little damage to the physical building due to flooding, and can be easily recovered after the flood. A parameter in the functional relationship should be utilized to describe the maximum damage a structure can recieve due to flooding. Since some structures may have variability even with the same general construction type and practices, the estimate of maximum damage should be given with a possible range.

To determine maximum damages a simple approach is described by the Bureau of Transport Economics in Austrilia. For a given construction type, define an average distribution of the assembly items in the structure. Then assign value to those items to determine their value relative to the value of the structure. Next define how succeptible each component may be to flooding. After an exercize in accounting a total maximm damage can be estimated. This should be repeated for many different variations of assembly comonents.

Assembly items of the buildings based on the proposal of the HAZUS technical manual (FEMA, 2012) have been categorized into five general groups:

- foundation and below first floor, which includes site work, footings, walls, slab, piles, and items that are located below the first floor of the structure;

- structure framing, which includes all of the main load carrying members below the roof and above the foundation;

- roof covering and roof framing;

- exterior walls, which includes wall coverings, windows, exterior doors and insulation; and

- interiors, which includes interior walls and floor framing, drywall, paint, interior trims, floor coverings, cabinets, and mechanical and electrical facilities.

\section{Evaluating the rate of damage accumulation}

As described in detail by the HAZUS technical manual and the Australian construction cost guide
(Rawlinsons, 2014), the replacement value of interiors and exterior walls, which can be damaged with very low incremental depths, are about $70 \%$ of the total replacement value of the building. This implies that for the first few feet of flood, the rate of damage to electrical equipment and insulation is greater than the remaining stages.

This implication yields insights into a general functional form that may describe damages relative to depth above a first floor of a structure. The function form would increase quickly and then slowly reach some maximum damage. A good representation of that form would be a power function where the power is between zero and 1 . To easily accomplish that, a root function using $1 / \mathrm{r}$ can be utilized.

Depth damage relationships should include some parameter that governs the shape of the depth damage function, and that parameter in this paper is referred to as $\mathrm{r}$.

\section{Constructing a functional model}

Based on the previous two sections, the following function could easily describe the damages for a single story building.

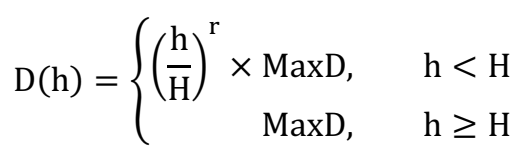

Where $\mathrm{D}$ is the damage calculated, $\mathrm{H}$ represents the total height of the building above the first floor, $h$ is the depth above first floor being evaluated, $r$ is the shape parameter, and then MaxD representing the maximum damage for the structure.

As described earlier, $r$ would be a value between 0 to 1 , so the shape of the function would generally follow the family of the square root functions, scaled by MaxD. MaxD would be between 0 and 100, so D would represent a number between 0 and 100, and would represent a percentage damaged at the structure based on depth.

For a structure with a single floor this equation is satisfactory. However, with additinoal stories, the accumulation of damage would accelerate at the transition for each new floor. To accomidate this, the equation can be modified in many ways. Generically a simple assumption of equally dividing value between floors could be used, or each floor could be separately described. Many multi story buildings have higher value in the first floor for electrical equipment. Some 
multi story buildings place the majority of that equipment on the roof. Depending on the construction practice of the structures, there may be reasons for unequal value allocation.

To unequally allocate value each ith floor would need a value described, but the sum of all floors would need to sum to MaxD. Additionally, the rate of damage within any floor might actually vary, which would be a different $r$ by floor. Each floor could have different heights, which would be a different $h$ for each floor.

$$
\operatorname{MaxD}=\sum_{\mathrm{i}=1}^{\mathrm{n}} \mathrm{Val}_{\mathrm{i}}
$$

Regardless of percentage value allocation, the damage would be expressed in an equation much like this.

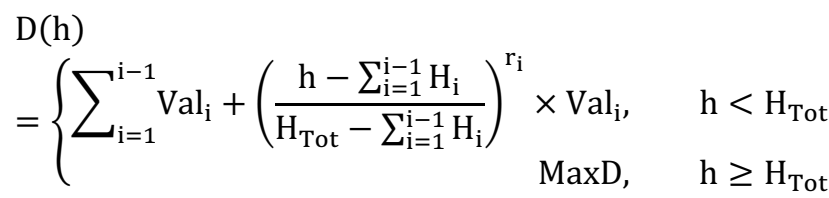

The assumption is that the total damageable value Val for each floor is reached once the height of the floor is exceeded.

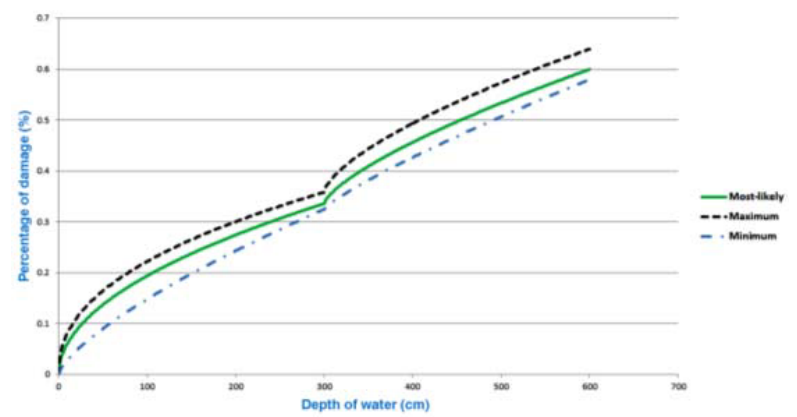

Figure 3

\section{Evaluating the goodness of fit}

For any empirical data, curves could be produced. To do so the data would need to be stratified by construction type. Further, the damage would need to represent only structure losses. Each stratification would need to have a starting value for the parameters $\mathrm{r}, \mathrm{H}$, and MaxD. By inputing the values into the proper equation, the function could be evaluated for each observed data element. The objective would be to minimize the sum of the error from the observed damages and the calcuated damages.
Other measures could be used like Chi Squared test could be utilized to define the goodness of fit.

\section{Evaluating an estimated curve from emprical data.}

The process in section seven would be duplicated for random selections of $\mathrm{r}, \mathrm{H}$ and $\mathrm{MaxD}$, provided the user gave a range of each parameter, and the set that produced the smallest cumulative error would be selected as the most likely curve.

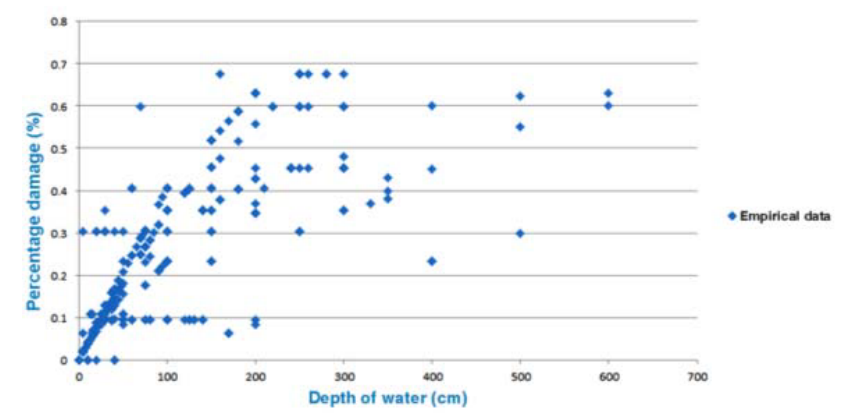

Figure 4

\section{Producing Epistimic Uncertainty}

Given the size of emperical datasets, it is likely that the sampled data may not represent the population of damage estimates within a region. To attempt to accomidate this issue, a bootstrapping methodology was utilized. The full dataset would be used to create a parameter set, and then many iterations of the process would take place, each addtional iteration would sample from the dataset with replacement. The set of parameters which maximize the depth damage relationship would be taken as a max curve, and the observation which created the minimum depth damage relationship would be taken as the minimum curve.

This would result in three curves. For simplicity, the curves could be treated as a triangular distribution.

Alternatively, each observed curve in the bootstrapping process could be sampled for eahc half foot increment in depth, which could be used to create a histogram of likely damages for each half foot increment. This could be stored as an empirical distribution and that could define the uncertainty about the depth damage relationship. 


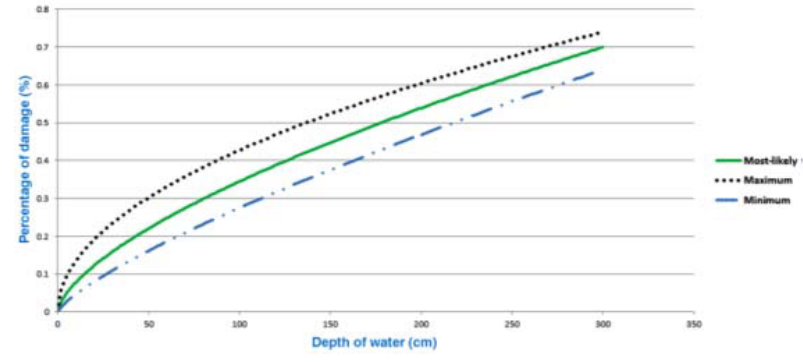

Figure 5

\section{Shortcomings}

While empirical data may be utilized to fit a curve with uncertainty ranges, there are many additional parameters that may govern the significance of the damages for a given depth that may not be accounted for in this simplistic model:
a. High velocity flows
b. Salinity of water
c. Long duration
d. High sediment loading
e. Early warning

These values may impact the accuracy of the proposed methodologies, and should be considered by the analyst when making risk mitigation decisions given the use of these depth damage relationships in the assessment of flood damages. Non quantitative analysis can be utilized by taking the charactersistics of the emperical data utilized to develop the curves, and comparing that to the expected floods in the location of interest and describing how these factors might impact the significance of flooding positively or negatively.

\section{Conclusion}

This functional relationship and analysis procedures provides a simple framework for taking depth damage observations, and creating depth damage relationships. It requires knowledge of the construction methodolgies, and practices in the region. The proccess seeks to provide depth damage curves that are customizeable to each reagion, but requires an analyst familiar with construction practices, and historic data.

The process produces depth damage relationships that are funcitonal, and expresses the uncertainty inherint in the evaluation of damages at a structure.

\section{References}

André, C., Monfort, D., Bouzit, M., and Vinchon, C.: Contribution of insurance data to cost assessment of coastal flood damage to residential buildings: insights gained from Johanna (2008) and

Xynthia (2010) storm events, Nat. Hazards Earth Syst. Sci., 13, 2003-2012, doi:10.5194/nhess-13-2003-2013, 2013.

Apel, H., Aronica, G. T., Kreibich, H., and Thieken, A. H.: Flood

risk analyses - how detailed do we need to be?, Nat. Hazards, 49, 79-98, 2009.

Barton, C., Viney, E., Heinrich, L., and Turnley, M.: The Reality of Determining Urban Flood Damages, in: NSW Floodplain Management

Authorities Annual Conference, Sydney, 2003.

Bundaberg Regional Council: Burnett River Floodplain - Bundaberg Ground Elevations [WWW Document], available at:

http://www.bundaberg.qld.gov.au/flood/mapping (last access: 30 September 2015), 2013 a.

Bundaberg Regional Council: Burnett River Catchment Map [WWW Document], available at: http://www.bundaberg.qld.gov.

au/flood/mapping (last access: 30 September 2015), $2013 \mathrm{~b}$.

Bundaberg Regional Council: 2013 Flood Calibration Map - Paradise

Dam to Bundaberg Port [WWW Document], available at: http://www.bundaberg.qld.gov.au/flood/mapping (last access: 30 September 2015), 2013c.

Bureau of Transport Economics: Economic Costs of Natural Disasters in Australia, Commonwealth of Australia, Canberra, 2001.

Cammerer, H., Thieken, A. H., and Lammel, J.: Adaptability and transferability of flood loss functions in residential areas, Nat.

Hazards Earth Syst. Sci., 13, 3063-3081, doi:10.5194/nhess-13-3063-2013, 2013.

Chai, T. and Draxler, R. R.: Root mean square error (RMSE) or mean absolute error (MAE)? - Arguments against avoiding RMSE in the literature, Geosci. 
Model Dev., 7, 1247-1250, doi:10.5194/gmd-7-12472014, 2014.

Chang, L. F., Lin, C. H., and Su, M. D.: Application of geographic weighted regression to establish flooddamage functions reflecting spatial variation, Water SA, 34, 209-216, 2008.

Comiskey, J. J.: Overview of Flood Damages Prevented by U.S. Army Corps of Engineers Flood Control Reduction Programs and Activities, J. Contemp. Water Res. Educ., 130, 13-19, 2005.

Dewals, B. J., Giron, E., Ernst, J., Hecq, W., and Pirotton, M.: Integrated assessment of flood protection measures in the context of climate change: Hydraulic modelling and economic approach,

Environ. Econ. Invest. Assess. II, 108, 149-159, 2008. Dunford, M. A., Power, L., and Cook, B.: National Exposure Information System (NEXIS) Building Exposure - Statistical Area Level 1 (SA1)[WWWDocument], available at: http://dx.doi.org/10.4225/25/5420C7F537B15 (last access: 15 July 2015), 2014.

Elmer, F., Thieken, A. H., Pech, I., and Kreibich, H.: Influence of flood frequency on residential building losses, Nat. Hazards Earth Syst. Sci., 10, 2145-2159, doi:10.5194/nhess-10-2145-2010, 2010.

Elmer, F., Hoymann, J., Düthmann, D., Vorogushyn, S., and Kreibich, H.: Drivers of flood risk change in residential areas, Nat. Hazards Earth Syst. Sci., 12, 1641-1657,doi:10.5194/nhess-12-1641-2012, 2012.

Emanuelsson, M. A. E., Mcintyre, N., Hunt, C. F., Mawle, R., Kitson, J., and Voulvoulis, N.: Flood risk assessment for infrastructure networks, J. Flood Risk Manage., 7, 31-41, 2014.

FEMA: Multi-Hazard Loss Estimation Methodology, Flood Model: Hazus-MH Technical Manual. Department of Homeland Security, Federal Emergency Management Agency, Mitigation Division, Washington, D.C., 2012.

Geoscience Australia: Flood Vulnerability Functions for Australian Buildings Summary of the Current Geoscience Australia Model Suite, Geoscience Australia, Canberra, 2012.

Gissing, A. and Blong, R.: Accounting for variability in commercial flood damage estimation, Aust. Geogr. 35, 209-222, 2004.
Jongman, B., Kreibich, H., Apel, H., Barredo, J. I., Bates, P. D., Feyen, L., Gericke, A., Neal, J., Aerts, J. C. J. H., and Ward, P. J.: Comparative flood damage model assessment: towards a European approach, Nat. Hazards Earth Syst. Sci., 12, 3733-3752, doi:10.5194/nhess-12-3733-2012, 2012.

Kaplan, S. and Garrick, B. J.: On the quantitative definition of risk, Risk Anal., 1, 11-27, 1981.

Kelman, I. and Spence, R.: An overview of flood actions on buildings, Eng. Geol., 73, 297-309, 2004.

Kourgialas, N. N. and Karatzas, G. P.: A hydroeconomic modelling framework for flood damage estimation and the role of riparian vegetation, Hydrol. Process., 27, 515-531, 2012.

Kreibich, H. and Thieken, A. H.: Assessment of damage caused by high groundwater inundation, Water Resour. Res., 44, 1-14, 2008.

Kreibich, H., Thieken, A. H., Petrow, Th., Müller, M., and Merz, B.: Flood loss reduction of private households due to building precautionary measures lessons learned from the Elbe flood in August 2002, Nat. Hazards Earth Syst. Sci., 5, 117-126, doi:10.5194/nhess-5-117-2005, 2005.

Kreibich, H., Seifert, I., Merz, B., and Thieken, A. H.: Developmentof FLEMOcs - a new model for the estimation of flood losses in the commercial sector, Hydrol. Sci. J., 55, 1302-1314, 2010.

Kundzewicz, Z. W., Ulbrich, U., Brücher, T., Graczyk, D., Krüger, A., Leckebusch, G. C., Menzel, L., Pi'nskwar, I., Radziejewski, M., and Szwed, M.: Summer floods in Central Europe - Climate change track?, Nat. Hazards, 36, 165-189, 2005.

Llasat, M. C., Marcos, R., Llasat-Botija, M., Gilabert, J., Turco, M., and Quintana-Seguí, P.: Flash flood evolution in North-Western Mediterranean, Atmos. Res., 149, 230-243, 2014.

McBean, E., Fortin, M., and Gorrie, J.: A critical analysis of residential flood damage estimation curves, Can. J. Civ. Eng. 13, 86-94, 1986.

Merz, B., Kreibich, H., Thieken, A., and Schmidtke, R.: Estimation uncertainty of direct monetary flood damage to buildings, Nat. Hazards Earth Syst. Sci., 4, 153-163, doi:10.5194/nhess-4-153-2004, 2004.

Merz, B., Kreibich, H., Schwarze, R., and Thieken, A.: Review article "Assessment of economic flood 
damage", Nat. Hazards Earth Syst. Sci., 10, 16971724, doi:10.5194/nhess-10-1697-2010, 2010.

Merz, B., Kreibich, H., and Lall, U.: Multi-variate flood damage assessment: a tree-based data-mining approach, Nat. Hazards Earth Syst. Sci., 13, 53-64, doi:10.5194/nhess-13-53-2013, 2013.

Meyer, V., Becker, N., Markantonis, V., Schwarze, R., van den Bergh, J. C. J. M., Bouwer, L. M., Bubeck, P., Ciavola, P., Genovese, E., Green, C., Hallegatte, S., Kreibich, H., Lequeux, Q., Logar, I., Papyrakis, E., Pfurtscheller, C., Poussin, J., Przyluski, V., Thieken, A. H., and Viavattene, C.: Review article: Assessing the costs of natural hazards - state of the art and knowledge gaps, Nat. Hazards Earth Syst. Sci., 13, 1351-1373, doi:10.5194/nhess-13-1351-2013, 2013.

Molinari, D.: FLOOD EARLY WARNING SYSTEMS PERFORMANCE: an approach at the warning chain perspective. PhD Thesis, Politecnico di Milano, 2011.

Molinari, D., Ballio, F., and Menoni, S.: Modelling the benefits of flood emergency management measures in reducing damages: a case study on Sondrio, Italy, Nat. Hazards Earth Syst. Sci., 13,

1913-1927, doi:10.5194/nhess-13-1913-2013, 2013.

Molinari, D., Ballio, F., Handmer, H., and Menoni, S.: On the modeling of significance for flood damage assessment, Int. J. Disaster Risk Reduct., 10, 381-391, 2014a.

Molinari, D., Menoni, S., Aronica, G. T., Ballio, F., Berni, N., Pandolfo, C., Stelluti, M., and Minucci, G.: Ex post damage assessment: an Italian experience, Nat. Hazards Earth Syst. Sci., 14,

901-916, doi:10.5194/nhess-14-901-2014, 2014 b.

Nadal, N. C., Zapata, R. E., Pagán, I., López, R., and Agudelo, J.: Building Damage due to Riverine and Coastal Floods. J. Water Resour. Plan. Manag., 136, 327-336, 2010.

Office of Environment and Heritage; New South Wales Government: Residential Flood Damage and supporting calculation spreadsheet [WWW Document], available at: http://www.environment.nsw.gov.au/floodplains/Stand ardFloodplainRiskManagement.htm (last access: 30 September 2015), 2007.
Queensland Department of Natural Resources and Mines: Interactive Floodcheck map [WWW Document], available at:

http://dnrmfloodcheck.esriaustraliaonline.com.au/flood check/, last access: 30 September 2015.

Queensland Government: Queensland Government Statistician's Office, Queensland Regional Profiles, Bundaberg Statistical Area Level 2 (SA2) [WWW Document], available at: http://statistics.qgso.qld.gov.au/qld-regionalprofiles? region-type $=$ SA2_11\&region-ids $=8075$ (last access: 15 July 2015), 2011a.

Queensland Government Queensland Government Statistician's Office, Queensland Regional Profiles, Maranoa Regional Council [WWW Document], available at: http://statistics.oesr.qld.gov.au/qldregional-profiles (last access: 30 April 2015), 2011 b.

Queensland Government: Queensland 2013 Flood Recovery Plan(for the events of January - February 2013) [WWW Document],available at: http://qldreconstruction.org.au/u/lib/cms2/lg-floodrecovery-plan.pdf (last access: 15 July 2015), 2013.

Rawlinsons: Australian Construction Cost Guide 2014, 32nd Edn.,Welshpool Publishing, Western Australia: Rawlinsons, 2014.

Scawthorn, C., Flores, P., Blais, N., Seligson, H., Tate, E., Chang, S., Mifflin, E., Thomas,W., Murphy, J., Jones, C., and Lawrence, M.: HAZUS-MH Flood Loss Estimation Methodology. II. Damage and Loss Assessment, Nat. Hazards Rev., 7, 72-81, 2006.

Schröter, K., Kreibich, H., Vogel, K., Riggelsen, C., Scherbaum, F., and Merz, B.: How useful are complex flood damage models?, Water Resour. Res., 50, 33783395, 2014.

Seifert, I., Kreibich, H., Merz, B., and Thieken, A. H.: Application and validation of FLEMOcs - a flood-loss estimation model for the commercial sector, Hydrol. Sci. J., 55, 1315-1324, 2010.

Smith, D.: Flood damage estimation-A review of urban stagedamage curves and loss function, Water SA, 20, 231-238, 1994.

Sturgess, R.: Rapid Appraisal Method (RAM) for Floodplain Management, 2000.

Thieken, A. H., Müller, M., Kreibich, H., and Merz, B.: Flood damage and influencing factors: New 
insights from the August 2002 flood in Germany, Water Resour. Res., 41, 1-16, 2005.

Thieken, A. H., Kreibich, H., and Merz, B.: Improved modelling of flood losses in private households, in: German-Polish Seminar "Natural Systems and Global Change", 1-10, 2006.

Thieken, A. H., Olschewski, A., Kreibich, H., Kobsch, S., and Merz, B.: Development and evaluation of FLEMOps - a new Flood Loss Estimation MOdel for the private sector. Flood Recover. Innov. Response, WIT Press, 315-324, 2008.

Thieken, A. H., Ackermann, V., Elmer, F., Kreibich, H., Kuhlmann, B., Kunert, U., Maiwald, H., Merz, B., Müller, M., Piroth, K., Schwarz, J., Schwarze, R., Seifert, I., and Seifert, J.: Methods for the evaluation of direct and indirect flood losses. In: RIMAX Contributions at the 4th International Symposium on Flood Defence

(ISFD4), 1-10, 2009.

UNISDR: UNISDR Terminology on Disaster Risk Reduction [WWW Document], available at: http:/www.unisdr.org/eng/terminology/terminology2009 (last access: 30 April 2015),2009.

USACE: Economic Guidance Memorandum (EGM) 04-01, Generic Depth-Damage Relationships for Residential Structures with Basements, 2003. 